\title{
Article \\ Individual and combined effects of two selected chemicals on bacterial load during transportation of tilapia (Oreochromis niloticus) fry
}

\author{
Md. Ali Reza Faruk, Sharmin Akter, Zannatul Ferdous and K. M. Shakil Rana* \\ Department of Aquaculture, Bangladesh Agricultural University, Mymensingh-2202, Bangladesh \\ *Corresponding author: K.M. Shakil Rana, Department of Aquaculture, Bangladesh Agricultural University, \\ Mymensingh-2202, Bangladesh. Phone: +8801728300299; E-mail: ranakms@bau.edu.bd
}

Received: 26 January 2019/Accepted: 20 February 2019/ Published: 31 March 2019

\begin{abstract}
The study evaluated the effects of two selected chemicals; methylene blue and saline on bacterial load in transport-water containing monosex tilapia (Oreochromis niloticus) fry. Fish fry was collected from a private hatchery located in Trishal upazilla, Mymensingh. A total of approximately 550 fry were added in each polyethylene bag containing water and transported to the Fish Disease Laboratory of the Department of Aquaculture, Bangladesh Agricultural University (BAU) for analysis. Two different concentrations of chemicals like 1 and $2 \mathrm{ppm}$ methylene blue, 1 and 2 ppt saline and combination of the both were used. Samplings were done at $0,4,8$ hours interval to determine the bacterial load in transport-water. Both methylene blue and saline were found effective in reducing bacterial load in water during transportation. The combined use of saline and methylene blue showed better result than the chemicals used individually in terms of final bacterial load. A gradual increase in bacterial load with time was found in control water having no chemicals $\left(T_{0}\right)$. In $T_{1}(1 \mathrm{ppm}$ methylene blue used) and $\mathrm{T}_{2}\left(2 \mathrm{ppm}\right.$ methylene blue used) the mean bacterial loads were $1.03 \pm 0.5 \times 10^{7} \mathrm{cfu} / \mathrm{ml}$ and $5.00 \pm 2 \times 10^{7} \mathrm{cfu} / \mathrm{ml}$ respectively. Similarly mean bacterial loads of $4.48 \pm 1.5 \times 10^{6} \mathrm{cfu} / \mathrm{ml}$ and $3.43 \pm 2.7 \times 10^{6}$ $\mathrm{cfu} / \mathrm{ml}$ were obtained with 1 and $2 \mathrm{ppt}$ saline $\left(\mathrm{T}_{3}\right.$ and $\left.\mathrm{T}_{4}\right)$ respectively. Whereas combined use of $1 \mathrm{ppm}$ methylene blue and $1 \mathrm{ppt}$ saline $\left(\mathrm{T}_{5}\right)$ end up with the mean bacterial load of $2.94 \pm 2.5 \times 10^{6} \mathrm{cfu} / \mathrm{ml}$ after 8 hours of exposure. It was $2.95 \pm 2.7 \times 10^{6} \mathrm{cfu} / \mathrm{ml}$ when the dose was doubled $\left(\mathrm{T}_{6}\right)$. The highest percentage of mortality was found in control water in every sampling period. Water quality parameters like temperature, $\mathrm{pH}$, and dissolved oxygen decreased after 8 hours of transportation. The experiment revealed that the combined low dose of methylene blue and saline can be recommended for transportation of tilapia fry.
\end{abstract}

Keywords: fry transportation; bacterial loads; methylene blue; saline; effects

\section{Introduction}

Fish hatcheries have been playing an important role in the expansion of aquaculture of Bangladesh. Quality and healthy fish seed is the prerequisite for sustainable aquaculture. Monosex GIFT tilapia (Oreochromis niloticus) is the leading species in aquaculture of Bangladesh and its farming is growing day by day. In last decades, over 400 tilapia hatcheries have been established and producing about 4.0-5.0 billion fry every year (DoF, 2016). The survival of fingerlings during transport from hatchery to grow-out farmers' farm is very critical to both of them. To deal with the problem, hatchery owners use some chemicals to prevent the proliferation of bacteria during fish transport. Methylene blue $\left(\mathrm{Cl}_{6} \mathrm{H}_{18} \mathrm{~N}_{3} \mathrm{CIS} .3 \mathrm{H}_{2} \mathrm{O}\right)$ and some commercially available saline are commonly used in different hatchery. Though the common composition is saline $\mathrm{NaCl}$, other components e.g. $\mathrm{NaHCO}_{3}$, $\mathrm{KCl}$, Dextrose, Vit A, $\mathrm{ZnSO}_{4}, \mathrm{CaCl}_{2}, \mathrm{MnSO}_{4}$ are used. According to Jensen (1990), fish losses from death or injury during transportation are the results of the activation of latent disease organisms or osmoregulatory problem. Experience and research have shown that fish transport can be improved by the addition of certain chemicals such as sodium chloride and methylene blue (Fajardo, 2002). Common table salt or sodium chloride is one of the most commonly used drugs in aquaculture and it is sometimes referred to as the "aspirin of 
aquaculture" (Swann and Fitzgerald, 1992). Weaker solutions containing salt may be used as a bath for several hours to eliminate some freshwater parasites and enhance mucus production and osmoregulation in freshwater fish during handling and transport (Francis-Floyd, 1995). Methylene blue is a redox dye which raises the oxygen consumption of cells. Methylene blue is also effective against superficial bacterial and fungal infections of fishes. It is safe for use with fish eggs and fry for the prevention of microbial infection. Methylene blue acts as an inhibitor of bacteria and fungi (Schaperclaus, 1992). It is also applied during quarantine treatment of aquarium fishes especially for breeders (Subasinghe, 1992). Fry morality during transportation is a common problem. In this regard, this study attempted to find out the effect of methylene blue and saline in the transport water with monosex tilapia (O. niloticus) fingerlings. Such a study would provide a fundamental basis for controlling the microbial load during transportation of fry.

\section{Materials and Methods}

\subsection{Preparation of transportable polyethylene bags}

The transportation route started from a commercial tilapia fish hatchery at Trishal in Mymensingh district and ended up to Bangladesh Agricultural University (BAU). Polyethylene bags each measuring $16 \times 26 \times 1.5$ inch were filled up with 3-3.5 liters of water from conditioning tank. Each polyethylene bag was lined with another plastic bag of the same dimension for additional protection against leakage. In order to determine the effects of chemicals on bacterial load in water during transportation of tilapia fry, different concentrations of methylene blue and saline were used (Table 1). Chemical concentrations in different treatments were fixed based on literature and ongoing farm practice. In saline the major compound is $\mathrm{NaCl}$ and in addition such as $\mathrm{NaHCO}_{3}$, $\mathrm{KCl}$, Dextrose, Vit A, $\mathrm{ZnSO} 4, \mathrm{CaCl}_{2}, \mathrm{MnSO} 4$ were also found. The chemicals (saline and methylene blue) were used at certain concentrations as a reference of farm practice and as based from the literature. The experimental fish were conditioned for one day in a concrete tank with aeration. No feeding was done to prevent the accumulation of feces that can deteriorate the water quality. A total 550 pieces $0.4-0.5 \mathrm{~g}$ sized of monosex tilapia fry were loaded per bag. Each bag was filled with oxygen $(2 / 3$ of the bag volume) immediately after mixing the chemicals to the water and loading the fry.

Table 1. Concentration of methylene blue and saline.

\begin{tabular}{ll}
\hline Treatment & Chemical doses \\
\hline $\mathrm{T}_{0}$ & Control (no chemical addition) \\
$\mathrm{T}_{1}$ & Methylene blue 1 ppm \\
$\mathrm{T}_{2}$ & Methylene blue 2 ppm \\
$\mathrm{T}_{3}$ & Saline 1 ppt \\
$\mathrm{T}_{4}$ & Saline 2 ppt \\
$\mathrm{T}_{5}$ & Saline and methylene blue 1 ppt $+1 \mathrm{ppm}$ \\
$\mathrm{T}_{6}$ & Saline and methylene blue 2 ppt $+2 \mathrm{ppm}$ \\
\hline
\end{tabular}

\subsection{Sampling for bacterial load}

To determine the bacterial load, water samples were collected in sterile glass bottle from designated poly bag at $0,4,8 \mathrm{~h}$ interval. Water samples were drawn to the Fish Disease Laboratory of the Department of Aquaculture, Bangladesh Agricultural University (BAU).

\subsection{Media used}

Soybean casein digest agar (TSA) having pancreatic digest of casine $15 \mathrm{~g}$, enzymatic digest of soybean $5 \mathrm{~g}$, and agar $15 \mathrm{~g}$ were used for counting bacterial load. For the preparation of the media, required amount of media was suspended into distilled water in a conical flask and the mixture was boiled on electric heater to dissolve completely. Media were sterilized for 15 minutes at a temperature of $121^{\circ} \mathrm{C}$ under 15 psi pressure. Then it was cooled down to around $50^{\circ} \mathrm{C}$ and was poured into previously sterilized petri dish.

\subsection{Determination of colony forming unit (cfu/ml)}

Bacterial counting was done using serial dilution technique and expressed as colony forming unit (cfu/ml). Colony forming unit were determined for the bacterial suspension, prepared according to the drop using soyabean casein digest agar plates. Serial dilution of bacterial suspensions taken from the water samples was done up to $10^{-5}$ in sterile distilled water. A volume of $20 \mu \mathrm{l}$ from suspension of each dilution was placed in prepared petri plates. The cover of the petri plates was marked into four divisions corresponding to the 
designated serial dilution. Each petri plate was replicated two times. The petri plates were allowed to dry and then they were incubated in an inverted position at $32^{\circ} \mathrm{C}$ for at least 24 hour until bacterial colonies were visible and could be counted. The average count of colonies from the designated division of each of the replicates was taken. The number of colony forming units per $\mathrm{ml}(\mathrm{cfu} / \mathrm{ml})$ of bacterial suspension was computed by adopting the following formula:

$\mathrm{cfu} / \mathrm{ml}=$ Average no. of colonies $\times$ dilution factor $\times 50$

\subsection{Recording of water quality parameter}

The water quality parameters were recorded in each sampling point throughout the experimental period. Water samples were collected from selected polybag. On each sampling, $10 \mathrm{ml}$ water was collected in a sterilized glass bottle with cap carefully without agitation. Each bottle was then marked with respective polybag. Water quality parameters such as temperature, dissolved oxygen, $\mathrm{P}^{\mathrm{H}}$ were measured using a commercial test kit (SERA test kit, Sera GbmH D 52518 Heinsberg, Germany). The aforementioned procedure was undertaken at each indicated time interval. Water temperature was recorded using thermometer.

\subsection{Determination of fry mortality}

The fingerling mortality was determined and gross examination of the physical appearances of the fingerlings was done at the end of the transport. The gathered data were analyzed into percentage.

\subsection{Data analysis}

Collected data were recorded using MS Excel 2007 version in the computer for statistical analysis. Duncan's New Multiple Range Test (Duncan, 1955) was employed with Excel-Stat software to test the significance of variation between the treatment means. The consequences have been presented in tabular and graphical forms.

\section{Results and Discussion}

Disinfection is a common disease management tool in aquaculture establishments. A chemical disinfectant prevents infection by inactivation of microorganisms pathogenic to aquatic animals. In fish hatchery to maintain a stable predictable production, elimination of mortality of fry in early life stages of development is very essential. Disinfectant improves the survival of fry by removing fungas and other disease agent that can affect successful growth of fry and fingerling and helpful for transportation of fry. Salt is inexpensive, readily available, and when properly administered, safe for use in freshwater fish. According to Swann and Fitzgerald (1992) it can be used to treat many external parasites including Costia, Epistylis, Trichodina, Chilodonella and flukes Dactilogyrus and Gyrodactylus. It can be used to treat external protozoan parasite and monogenetic trematodes (Plumb, 1992), and as prophylaxis against external parasites of freshwater fishes (Baticados and Paclibare, 1992). The effects of salt on fish are determined both by salt concentration and duration of exposure (Francis-Floyd, 1995). According to Swann and Fitzgerald (1992), the method of salt application depends on the disease organism, fish species, weight and types of aquaculture unit. In this study saline was used as disinfectant of fry in polybag during transportation at different concentrations. As a well redox dye, methylene blue raises the oxygen consumption of cells. It is also excellent against methemoglobin intoxication (Schaperclaus, 1992). The therapeutic action of methylene blue on bacteria and other parasites is probably due to its binding effect with cytoplasmic structures within the cell and also its interference with oxidation-reduction processes. Methylene blue may be used for the treatment of Ichthyophthiriosis (white spot disease), skin and gill flukes, velvet disease, Costiasis, coral fish disease, Chilodonelliasis and as a palliative medicine in all cases of disease of the gills, where fishes suffer from difficulty in breathing (Van Duijn, 1973). In the present study, methylene blue was used as an inhibitor of bacteria and fungi. It was also reported by Schaperclaus (1992). Indeed for the local availability and convenient use of these chemicals provoked to use methylene blue and salt (saline) as bacterial inhibitor during fish transportation. In the present study, both methylene blue and saline or salt were effective in reducing the bacterial counts in the water during 8 hour transport of mono-sex tilapia fry. Influence of chemicals in water during transportation of tilapia fry was determined at different time interval using colony forming unit (cfu)/ml. Bacterial loads in the water at 0,4 and 8 hours of transport are presented in Table 2 . 
Table 2. Bacterial loads in the transport-water of different treatments over 8 hours.

\begin{tabular}{|c|c|c|c|c|}
\hline \multirow{2}{*}{ Treatments } & \multicolumn{3}{|c|}{ Bacterial count $(\mathrm{cfu} / \mathrm{ml})$} & \multirow{2}{*}{-Mean \pm SD } \\
\hline & 0-hour & 4-hour & 8-hour & \\
\hline $\mathrm{T}_{0}$ & $8.10 \times 10^{7 a}$ & $1.11 \times 10^{8 \mathrm{f}}$ & $1.62 \times 10^{8 \mathrm{~d}}$ & $1.15 \pm 0.3 \times 10^{8}$ \\
\hline $\mathrm{T}_{1}$ & $1.60 \times 10^{7 \mathrm{f}}$ & $9.00 \times 10^{6 \mathrm{a}}$ & $6.00 \times 10^{6 a}$ & $1.03 \pm 0.5 \times 10^{7}$ \\
\hline $\mathrm{T}_{2}$ & $8.10 \times 10^{7 a}$ & $5.60 \times 10^{7 b}$ & $1.20 \times 10^{7 \mathrm{e}}$ & $5.00 \pm 2 \times 10^{7}$ \\
\hline $\mathrm{T}_{3}$ & $6.20 \times 10^{6 \mathrm{~b}}$ & $4.11 \times 10^{6 c}$ & $3.13 \times 10^{6 c}$ & $4.48 \pm 1.5 \times 10^{6}$ \\
\hline $\mathrm{T}_{4}$ & $5.90 \times 10^{6 c}$ & $3.90 \times 10^{6 \mathrm{~d}}$ & $4.90 \times 10^{5 b}$ & $3.43 \pm 2.7 \times 10^{6}$ \\
\hline $\mathrm{T}_{5}$ & $4.90 \times 10^{6 \mathrm{e}}$ & $3.80 \times 10^{6 \mathrm{~d}}$ & $1.20 \times 10^{5 \mathrm{~g}}$ & $2.94 \pm 2.5 \times 10^{6}$ \\
\hline $\mathrm{T}_{6}$ & $5.60 \times 10^{6 \mathrm{~d}}$ & $3.10 \times 10^{6 \mathrm{e}}$ & $1.50 \times 10^{5 \mathrm{f}}$ & $2.95 \pm 2.7 \times 10^{6}$ \\
\hline Level of significance & $* *$ & $* *$ & $* *$ & \\
\hline $\operatorname{LSD}_{(0.05)}$ & 4.895 & 6.150 & 4.217 & \\
\hline $\mathrm{CV}(\%)$ & 0.74 & 1.26 & 1.45 & \\
\hline
\end{tabular}

Mean values with the same superscript letter(s) were not significantly different $(\mathrm{P}>0.05)$;

$* *=$ Significant at $5 \%$ level of probability

The bacterial counts in Treatments 1,2, 3, 4, 5 and 6 decreased with the increase of time (Figures 1 and 2).

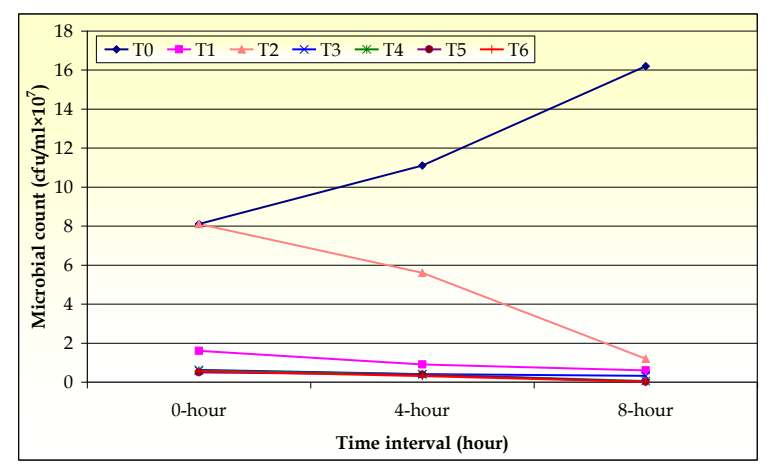

Figure 1. Bacterial load with the course of transportation time in different treatments.

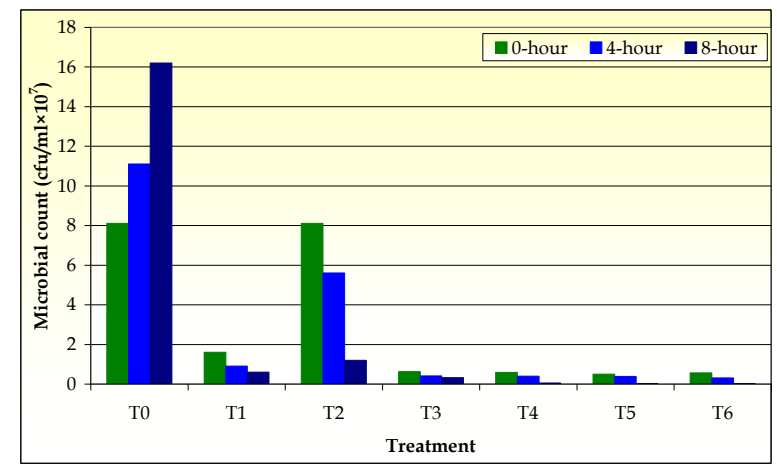

Figure 2. Changes of bacterial loads in different treatments over time.

Treatment 2 had the highest initial bacterial count of $8.10 \times 10^{7} \mathrm{cfu} / \mathrm{ml}$ and decreased to $1.20 \times 10^{7} \mathrm{cfu} / \mathrm{ml}$ after 8 hours while the lowest initial bacterial load recorded in $T_{5}\left(4.90 \times 10^{6} \mathrm{cfu} / \mathrm{ml}\right)$ that was significantly decreased to $1.20 \times 10^{5} \mathrm{cfu} / \mathrm{ml}$ at the end of transport. Likewise bacterial counts in treatment 1, 3, 4 and 6 also decreased significantly except $\mathrm{T}_{0}$ (control). Fish in $\mathrm{T}_{0}$ experienced increased bacterial loads with the passes of time, started from $8.10 \times 10^{7} \mathrm{cfu} / \mathrm{ml}$ and end up at $1.62 \times 10^{8} \mathrm{cfu} / \mathrm{ml}$. Analysis of variance at 4 hours and at 8 hours of the bacterial load in the transport water implied that there were significant differences among treatments $(\mathrm{P}<0.05)$. Normally mortality cause due to stress and time of transport. The survival of fingerlings during transport is very critical to both hatchery owners and grow-out operators. 
Table 3. Mortality (\%) of tilapia fry during transportation.

\begin{tabular}{llllllll}
\hline Parameters & \multicolumn{9}{c}{ Treatments } \\
\cline { 2 - 8 } & $\mathrm{T}_{0}$ & $\mathrm{~T}_{1}$ & $\mathrm{~T}_{2}$ & $\mathrm{~T}_{3}$ & $\mathrm{~T}_{4}$ & $\mathrm{~T}_{5}$ & $\mathrm{~T}_{6}$ \\
\hline Average no. of mortality & 40 & 15 & 5 & 2 & 14 & 20 & 12 \\
Mortality (\%) & 7.27 & 2.72 & 0.91 & 0.36 & 2.55 & 3.64 & 2.18 \\
Survival (\%) & 92.73 & 97.28 & 99.09 & 99.64 & 97.45 & 96.3 & 97.82 \\
\hline
\end{tabular}

Table 3 showed that the highest percentage of mortality was found in control $\mathrm{T}_{0}(7.27 \%)$, followed by $\mathrm{T}_{5}(3.64$ $\%)$, then by $\mathrm{T}_{1}(2.72 \%)$. Treatment 3 had the lowest mortality with $0.36 \%$. Analysis of variance showed that there wereno significant differences on the percentage mortality among treatments $(\mathrm{P}>0.05)$.

Table 4. Water quality parameters in various treatments.

\begin{tabular}{|c|c|c|c|c|c|c|c|c|}
\hline \multirow[t]{2}{*}{ Parameters } & \multirow[t]{2}{*}{ Duration of transport(h) } & \multicolumn{7}{|c|}{ Treatments } \\
\hline & & $\mathrm{T}_{0}$ & $\mathrm{~T}_{1}$ & $\mathrm{~T}_{2}$ & $\mathrm{~T}_{3}$ & $\mathrm{~T}_{4}$ & $\mathrm{~T}_{5}$ & $\mathrm{~T}_{6}$ \\
\hline \multirow{3}{*}{$\mathrm{P}^{\mathrm{H}}$} & 0 & 8.0 & 7.5 & 7.5 & 8.0 & 8.0 & 7.5 & 7.5 \\
\hline & 4 & 7.5 & 7.5 & 7.0 & 7.5 & 7.5 & 7.5 & 7.0 \\
\hline & 8 & 7.5 & 7.0 & 7.0 & 7.0 & 7.0 & 7.0 & 7.0 \\
\hline \multirow{3}{*}{ Dissolved oxygen $(\mathrm{mg} / \mathrm{l})$} & 0 & 6.0 & 6.0 & 6.0 & 6.0 & 6.0 & 6.0 & 6.0 \\
\hline & 4 & 6.0 & 4.0 & 4.0 & 4.0 & 6.0 & 4.0 & 4.0 \\
\hline & 8 & 4.0 & 4.0 & 4.0 & 4.0 & 4.0 & 4.0 & 4.0 \\
\hline \multirow{3}{*}{ Temperature } & 0 & 31 & 28 & 28 & 30 & 31 & 31 & 30 \\
\hline & 4 & 30 & 28 & 28 & 30 & 30 & 30 & 30 \\
\hline & 8 & 27 & 26 & 27 & 29 & 28 & 28 & 28 \\
\hline
\end{tabular}

It was also observed that there were no changes in the physical appearances and behavior of the fry before, during and after the transport. The water quality parameters of transported water were recorded using commercial test kits (Table 4). Initial $\mathrm{pH}$ values were high in all treatments while $\mathrm{pH}$ values were decreased with time interval after 4 and 8 hours. After 8 hours in all treatments $\mathrm{pH}$ values was 7.0 except control. Initially dissolved oxygen concentration was high $(6 \mathrm{mg} / \mathrm{l})$ in all treatments which was decreased to $4 \mathrm{mg} / \mathrm{l}$ at the end of transport in all the treatments. Temperature readings from 0 to 8 hours decreased in all treatments. Temperature at 0 hour ranged from 28 to $31^{\circ} \mathrm{C}$ and decreased from 26 to $29^{\circ} \mathrm{C}$ after 8 hours of transport. During transportation treatment with methylene blue and saline showed that the bacterial load was reduced after 8 hours of transportation while in control water bacterial load was increased after time interval. It was found that higher dose of methylene blue ( $2 \mathrm{ppm}$ ) in $\mathrm{T}_{2}$ significantly reduced the bacterial load than lower dose of methylene blue $(1 \mathrm{ppm})$ in $\mathrm{T}_{1}$ over the transportation time. In treatment 1 and 2 the mean bacterial load was observed $1.03 \pm 0.5 \times 10^{7} \mathrm{cfu} / \mathrm{ml}$ and $5.00 \pm 2 \times 10^{7} \mathrm{cfu} / \mathrm{ml}$ respectively after 8 hour of transportation while methylene blue was used at 1 and $2 \mathrm{ppm}$. Bolivar et al. (2012) reported that the highest decrease of bacteria was associated with higher dosage of methylene blue used compared to the lower concentration of methylene blue. Similarly, when saline was used at high concentration $(2 \mathrm{ppt})$ in $\mathrm{T}_{4}$ obtained greater decrease in bacterial count than lower concentration ( $1 \mathrm{ppt}$ ) in $\mathrm{T}_{3}$ after 8 hours of exposure. The mean bacterial count in $\mathrm{T}_{3}$ and $\mathrm{T}_{4}$ were $4.48 \pm 1.5 \times 10^{6}$ $\mathrm{cfu} / \mathrm{ml}$ and $3.43 \pm 2.7 \times 10^{6} \mathrm{cfu} / \mathrm{ml}$ respectively. This result also conforms to Bolivar et al. (2012) that lower dose of salt showed higher bacterial load and higher dose of salt showed lower bacterial count after 8 hour of exposure. The combination of both the chemicals at both concentrations showed comparatively lower mean bacterial load after 8 hours of transportation than the individual use of each chemical alone. Whereas $\mathrm{T}_{5}$ (saline and methylene blue $1 \mathrm{ppt}+1 \mathrm{ppm}$ ) resulted in lower decrease of bacterial load than $\mathrm{T}_{6}$ (saline and methylene blue $2 \mathrm{ppt}+2 \mathrm{ppm}$ ) which is probably due to the combined activities of two chemicals of the experiment was not favorable for the growth of bacteria. After 8 hours of transportation the mean bacterial loads were found $2.94 \pm 2.5 \times 10^{6} \mathrm{cfu} / \mathrm{ml}$ and $2.95 \pm 2.7 \times 10^{6} \mathrm{cfu} / \mathrm{ml}$ in treatment 5 and 6 respectively while in control water $\left(\mathrm{T}_{0}\right)$ was $1.15 \pm 0.3 \times 10^{8} \mathrm{cfu} / \mathrm{ml}$. The results revealed that there were differences among treatments on bacterial count at 0 and 8 hour of transport. There was decrease of bacterial count after 8 hour of exposure. But on the other hand, there was increase of bacterial count after 8 hour in control condition while there was no chemical used.

\section{Conclusions}

Fish hatchery plays a vital role in providing quality seeds in the aquaculture sector. Without good quality seed higher production and sustainability is not possible. To ensure quality and healthy seed production different 
types of chemicals and drugs are used for different purposes of hatchery operation. After hatching fry and fingerlings are transported for short and long distance for different time interval. During transportation various chemicals are used for reduction of bacterial load in transported polybag. The present study highlighted the use of two selected chemicals e.g. methylene blue and saline in water with fry transported polybag and examined the effect of two chemicals on bacterial loads. Consequently concluded that both methylene blue and saline (salt) could significantly reduce bacterial loads during transportation but their combination could fetch more effective results. However further research is needed to specify the best combination of chemicals at cost effective manner to reduce deleterious bacterial effects during fish fry transportation.

\section{Conflict of interest}

None to declare.

\section{References}

Baticados MCL and JO Paclibare, 1992. The use of chemotherapeutic agents in aquaculture in the Philippines. In: Diseases in Asian aquaculture journal fish health section. Edited by: Sheriff M, RP Subasinghe and JR Arthur, Asian Fisheries Society, Manila, Philippines. pp. 531-546.

Bolivar RB, AD Michael, GG Aragones and Garcia, 2012. Effect of methylene blue and sodium chloride on the bacterial load in the transportation water with Nile tilapia Oreochromis niloticus fingerling. Phil. Uni. J. Bio. Sci., 5: 188-198.

DoF, 2016. Fish week compendium, Department of Fisheries. Ministry of Fisheries and livestock, Dhaka, Bangladesh. pp. 21-148.

Fajardo LJ, 2002. Effect of zeolitic material on ammonia concentration during fish transport. Undergraduate Thesis. College of Fisheries, Central Luzon State University, Science City of Muñoz, Nueva Ecija. pp. 1134.

Francis-Floyd R, 1995. The use of salt in aquaculture. Florida Co-operative Extension Service, Fact Sheet VM 86, Institute of Food and Agricultural Sciences, University of Florida, USA.

Jensen GL, 1990. Transportation of warm water fish equipment and guidelines. SRAC (Southern Regional Aquaculture Center) Publication, USA.

Plumb JA, 1992. Disease control in aquaculture. In: diseases in Asian aquaculture journal fish health section. Edited by: Sheriff M, RP Subasinghe and JR Arthur, Asian Fisheries Society: Manila, Philippines. pp. 578587.

Schaperclaus W, 1992. Fish Diseases (Vol. 1). AA Balkeema Publication, Rotterdam, Netherland.

Subasinghe RP, 1992. The Use of chemotherapeutic agents in aquaculture in SriLanka. In: Diseases in Asian Aquaculture Journal Fish Health Section. Edited by: Sheriff M, RP Subasinghe, and JR Arthur, Asian Fisheries Society: Manila, Philippines. pp. 547-554.

Swann L and S Fitzgerald, 1992. Use and application of salt in aquaculture. NCRAC (North Central Regional Aquaculture Center) Extension Fact Sheets. pp.9-32.

Van Duijn CJ, 1973. Diseases of Fishes ( $3^{\text {rd }}$ edition). Butterworth and Co. Ltd., London. 